\title{
Harvesting Season and Botanical Origin Interferes in Production and Nutritional Composition of Bee Pollen
}

\author{
ADRIANA F. NEGRÃO ${ }^{1}$ and RICARDO O. ORSI ${ }^{2}$ \\ ${ }^{1}$ Faculdade de Medicina Veterinária e Zootecnia, Universidade Estadual Paulista/UNESP, Campus Botucatu, \\ Rua Dr. José Barbosa de Barros, 1780, Fazenda Experimental Lageado, 18610-307 Botucatu, SP, Brazil \\ ${ }^{2}$ Departamento de Produção Animal, Faculdade de Medicina Veterinária e Zootecnia, Universidade Estadual Paulista/ \\ UNESP, Campus Botucatu, Rua Prof. Dr. Walter Maurício Correa, s/n, Caixa Postal 560, 18618-681 Botucatu, SP, Brazil
}

Manuscript received on March 16, 2016; accepted for publication on May 9, 2016

\begin{abstract}
We aimed to evaluate the frequency of bee pollen production, its botanical origin and chemical composition when collected in different seasons. Our results indicate that higher proteins $(22.80 \pm 3.09 \%)$ and flavonoids $\left(2789.87 \pm 1396.00 \mu \mathrm{g} 100 \mathrm{~g}^{-1}\right)$ levels were obtained in the winter season, which also showed greater pollen production (134.50 \pm 35.70 grams) and predominance of the Myrtaceae family. As for spring we found high concentrations of lipids $(4.62 \pm 2.26 \%)$ and low ash content $(2.22 \pm 0.39 \%)$. Regarding the amino acid composition and vitamin $\mathrm{C}$ content, we found no differences between the averages throughout the seasons. Our results highlight the importance of understanding not only the botanical origin and the chemical composition of bee pollen, but also the harvesting frequency of this product by bees, so that it becomes possible to supplement the colonies in times of natural food resources shortage.
\end{abstract}

Key words: Apis mellifera, bee flora, bee nutrition, seasonality, protein content.

\section{INTRODUCTION}

The pollen grains - collected by honeybee Apis mellifera - are microscopic structures (which contains the plants male reproductive cell) found in the anthers of the flower stamens. Bees gather the grains collected by adding your salivary substances rich in enzymes, amino acids and vitamins, turning it into the bee pollen, causing it holds a different quality and quantity of substances contained in flowers pollen (Pchelovodstvo 1999, Campos et al. 2008).

Correspondence to: Ricardo de Oliveira Orsi

E-mail: orsi@fmvz.unesp.br
Pollen represents the main source of proteins, amino acids, carbohydrates and lipids to bees and contains other components such as, minerals and trace elements, vitamins and carotenoids, phenolic compounds, flavonoids, sterols and terpenes (Bogdanov 2011), and the product quantity and quality harvested by these insects can affect their reproduction, the brood care and individual life span, besides the colony productivity (Human and Nicolson 2006). It is also known that the pollen composition may vary according to the plant species, environmental conditions, among the seasons, and in different locations (Szczesna et al. 2002). 
Studies regarding the nutritional composition of bee pollen were carried out in different regions, such as, Brazil (Arruda et al. 2013), Portugal (Estevinho et al. 2012), South Africa (Nicolson and Human 2013) and China (Yang et al. 2013), but no studies have examined what were the production and chemical composition changes of bee pollen when it is collected in different seasons.

This work aimed to evaluate the frequency of bee pollen production in a given region, its botanical origin and chemical composition when collected in different seasons. Our results provide new information to contribute to the bee nutrition, being used as an auxiliary strategy in swarms' protein feeding, in times of shortage or when product quality is lower.

\section{MATERIALS AND METHODS}

\section{POLLEN SAMPLES}

The bee pollen samples were produced and collected, by frontal pollen trap collectors, three times a week from five hives housed at the Lageado Experimental Farm Beekeeping Production Area, UNESP (22 $50 ` 30,16^{\prime}$ 'S x 48 $25^{\circ}$ '41,90”W), located in Botucatu, in the State of São Paulo, Brazil, characterized by a Cfa climate according to the Köppen climate classification system (Köppen and Geiger 1928) between June 2010 and May 2011. At the end of each harvest, the bee pollen in natura taken from collectors was mixed and weighed on an analytical balance to measure the production. Next to prevent microorganisms growth the product was dried out in a controlled temperature oven (40 ${ }^{\circ} \mathrm{C}$ ) for 8 - 12 hours, until the pollen reached a $4 \%$ moisture content and then cleaned to remove impurities. After the pollen samples were frozen $\left(-12{ }^{\circ} \mathrm{C}\right)$ after drying, to preserve the quality until the chemical analysis was performed.

\section{CHEMICAL ANALYSES}

\section{Total protein}

$0.7 \mathrm{~g}$ of the samples were digested in a macro Kjeldahl flask. To determine the total protein, the nitrogen values were multiplied by conversion factor 6.25 (Roulston et al. 2000).

\section{Amino acid}

The composition was determined by acid hydrolysis, with the exception of tryptophan, which was analyzed on basic hydrolysis, by High Performance Liquid Chromatography (HPLC) according to the methodology of Araújo et al. 2007.

Lipids

Were determined by gravimetry. For this, $2 \mathrm{~g}$ of milled pollen were extracted in heat petroleum ether, in a Soxhlet apparatus, during a four-hour period (Almeida-Muradian et al. 2005).

Ashes

Two grams of previously weighed milled pollen were placed in a porcelain crucible and then incinerated in an oven at $550{ }^{\circ} \mathrm{C}$ until white ash was obtained. After the sample had been cooled in a desiccator, the ashes were determined by gravimetry (Almeida-Muradian et al. 2005).

\section{Vitamin $C$}

The determination of ascorbic acid by Tillmans method was performed by titration, based on the reduction of the dye 2,6-dichlorophenol indophenol by ascorbic acid. Ascorbic acid was added to react with the oxidized indicator 2,6-dichlorophenol indophenol in order to produce a colorless compound (IAL 2005). 


\section{Total flavonoids}

The analysis was performed according to the spectrophotometric method adapted from Santos and Blatt (1998) and Awad et al. (2000). The absorbance reading was done at $425 \mathrm{hm}$ and results expressed in $\mu \mathrm{g}$ flavonoids $\mathrm{g}^{-1}$ fresh weight equivalent of rutin.

\section{Pollen analysis}

Pollen analysis was performed using the Erdtman (1960) acetolysis method, and subsequently carried out the slides assembly with gelatin-glycerin, in triplicate, containing the material for observation with optical microscopy. Through qualitative analysis were determined botanical families, taking into account morphologic features of grains (Moreti et al. 2007). The floristic list follows the lines of the Cronquist (1988) system. Quantitative analysis was performed by counting 300 pollen grains (Barth $1998)$, these being grouped as: dominant pollen ( $>45 \%$ of total pollen sum); accessory pollen (15$44 \%$ of the total pollen sum); important isolated pollen (3-15\% of total pollen sum) and occasional isolated pollen $(<3 \%$ of total pollen sum).

\section{STATISTICAL ANALYSIS}

The results were reviewed by ANOVA followed by Tukey's test to verify the differences between the means. These were considered statistically different when $(\mathrm{P}<0.05)($ Zar 2010).

\section{RESULTS}

For the bee pollen in natura production, we observed that the highest average was obtained in the winter season being different from the other seasons, and the lowest production was obtained during the autumn (Fig. 1).

Regarding the palynological data, we identified a total of 14 botanical families and 3 pollen types (Fig. 2). We verified that the families Poaceae sp.1,

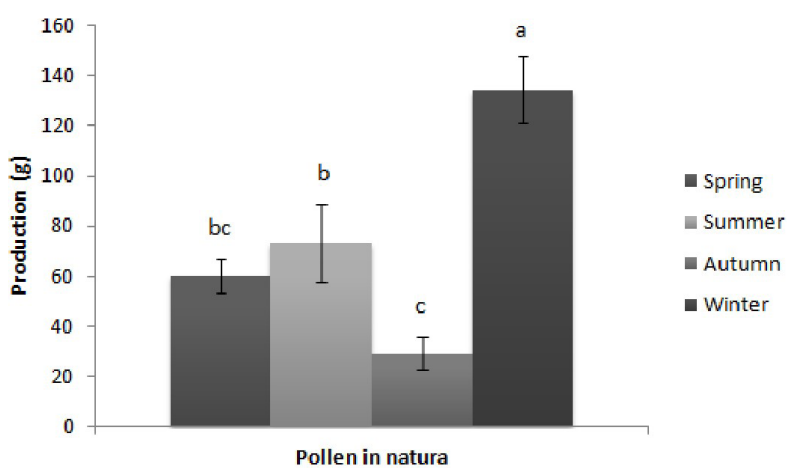

Figure 1 - Bee pollen in natura production averages, collected in different seasons by Apis mellifera L.

Myrtaceae sp.1 and Asteraceae sp.1 were found in all studied seasons (Table I).

In the spring we identified 9 botanical families and 1 pollen type, and the families Mimosaceae, Myrtaceae sp. 1 and Poaceae sp.2 were classified a accessory pollen by presenting a frequency of 15 to $44 \%$ of counted pollen (Table I). In the summer, 7 botanical families and 1 pollen type were identified and the families Asteraceae sp.1 and Mimosaceae were classified as accessory pollen (Table I).

The autumn season showed lower botany variation, being found only 5 families and 1 pollen type. The Fabaceae sp.2 and Salicaceae families were classified as occasional isolated pollen by presenting less than $3 \%$ of the total counted grains (Table I).

In winter we found 5 families and 1 pollen type and the Myrtaceae sp. 1 family was classified as dominant pollen once was present in over $45 \%$ of all counted grains (Table I). Regarding the nutritional composition, for crude protein we found a higher content for the winter period, significantly differing from the other seasons (Table II).

The spring showed the highest lipid content, differing from the summer and autumn, which had the lowest levels (Table II). As for the ash content, the spring season had the lowest average, being statistically different only from autumn period, which had the highest content (Table II). 


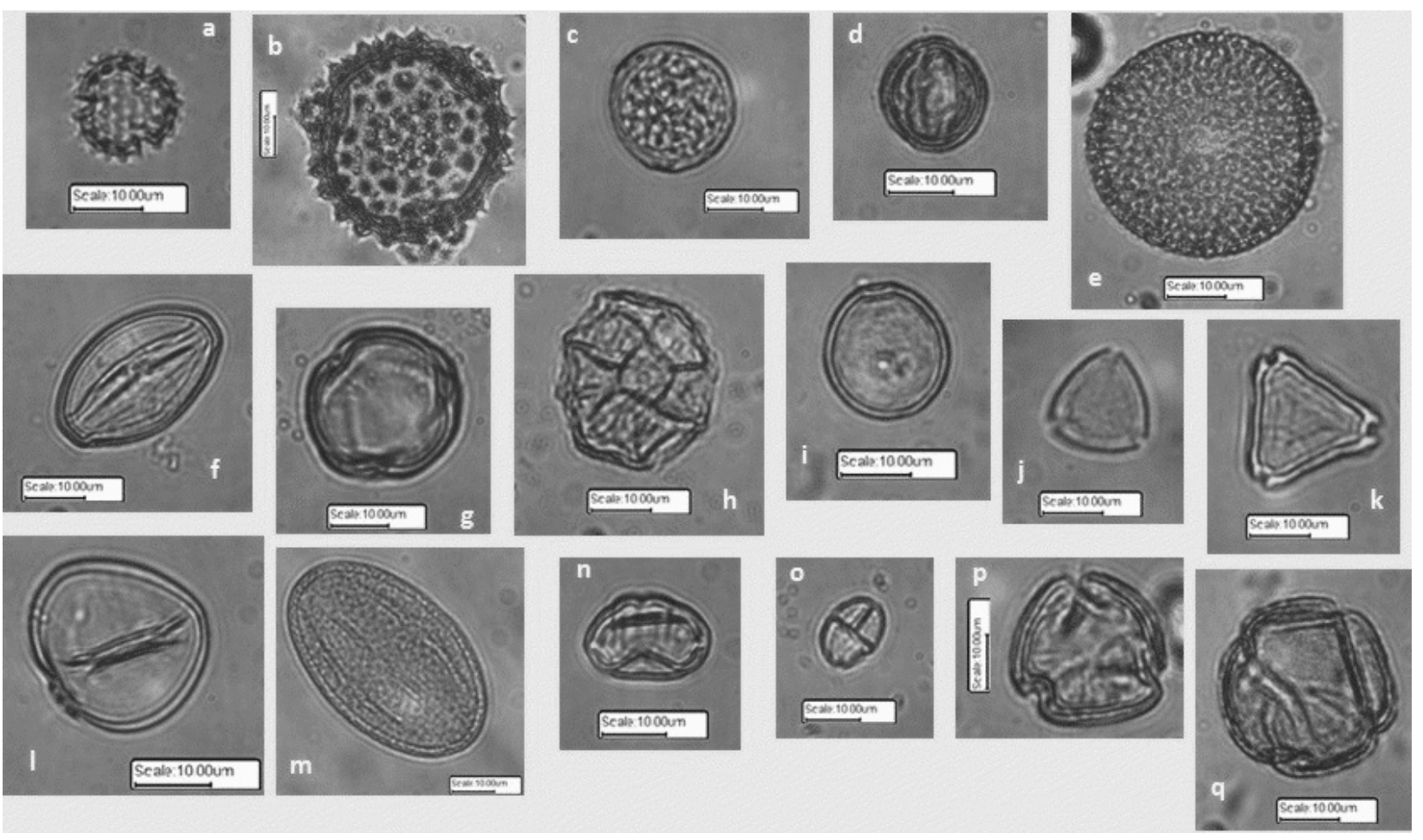

Figure 2 - Pollen grains found in bee pollen collected in different seasons: (a) Asteraceae sp.1; (b) Asteraceae sp.2; (c) Brassicaceae; (d) Combretaceae; (e) Euphorbiaceae; (f) Fabaceae sp.1; (g) Fabaceae sp.2; (h) Mimosaceae; (i) Poaceae sp.2; (j) Myrtaceae sp.2; (k) Myrtaceae sp.1; (l) Poaceae sp.1; (m) Salicaceae; (n) Urticaceae; (o) Pollen type 1; (p) Pollen type 2; (q) Pollen type 3.

TABLE I

Botanical families found in bee pollen samples collected by Apis mellifera in different seasons.

\begin{tabular}{|c|c|c|c|c|}
\hline \multirow[b]{2}{*}{$\begin{array}{c}\text { POLLEN TYPE } \\
\text { (Family) }\end{array}$} & \multicolumn{4}{|c|}{ Seasons } \\
\hline & $\begin{array}{c}\text { SPRING } \\
\text { (Sep/Oct/Nov) }\end{array}$ & $\begin{array}{c}\text { SUMMER } \\
\text { (Dec/Jan/Feb) }\end{array}$ & $\begin{array}{c}\text { AUTUMN } \\
\text { (Mar/Apr/May) }\end{array}$ & $\begin{array}{c}\text { WINTER } \\
\text { (Jun/Jul/Aug) }\end{array}$ \\
\hline Asteraceae sp. 1 & IIP & AP & AP & IIP \\
\hline Asteraceae sp. 2 & IIP & - & - & IIP \\
\hline Brassicaceae & IIP & - & - & - \\
\hline Combretaceae & IIP & - & - & IIP \\
\hline Euphorbiaceae & - & OIP & - & - \\
\hline Fabaceae sp. 1 & OIP & - & - & - \\
\hline Fabaceae sp. 2 & - & IIP & OIP & - \\
\hline Mimosaceae & AP & $\mathrm{AP}$ & - & - \\
\hline Myrtaceae sp. 1 & AP & IIP & IIP & DP \\
\hline Myrtaceae sp. 2 & - & - & - & IIP \\
\hline Poaceae sp. 1 & OIP & IIP & $\mathrm{AP}$ & IIP \\
\hline Poaceae sp. 2 & AP & - & - & - \\
\hline Salicaceae & - & - & OIP & - \\
\hline Urticaceae & - & OIP & - & - \\
\hline Pollen type 1 & - & - & $\mathrm{AP}$ & OIP \\
\hline Pollen type 2 & - & OIP & - & - \\
\hline Pollen type 3 & IIP & - & - & OIP \\
\hline
\end{tabular}

Quantitative analysis by counting 300 pollen grains. Dominant Pollen (DP) - over 45\% of total pollen sum; Accessory Pollen (AP) - 15 to 44\%; Isolated Important Pollen (IIP) - 3 to 15\% and Occasional Isolated Pollen (OIP) - less than 3\%. 
TABLE II

Chemical composition of bee pollen collected by Apis mellifera in different seasons.

\begin{tabular}{|c|c|c|c|c|c|}
\hline Seasons & $\mathrm{CP}(\%)$ & LP $(\%)$ & Ashes $(\%)$ & $\begin{array}{c}\text { Vitamin C } \\
\left(\mathrm{mg} 100 \mathrm{~g}^{-1}\right)\end{array}$ & $\begin{array}{l}\text { Flavonoids } \\
\left(\mu \mathrm{g} 100 \mathrm{~g}^{-1}\right)\end{array}$ \\
\hline SPRING (Sep. Oct. Nov.) & $21.00 \pm 2.15 b$ & $4.62 \pm 2.26 \mathrm{a}$ & $2.22 \pm 0.39 b$ & $0.90 \pm 0.32 \mathrm{a}$ & $2219.26 \pm 1233.90 b$ \\
\hline SUMMER (Dec. Jan. Feb.) & $20.92 \pm 1.94 b$ & $2.28 \pm 0.52 b$ & $2.45 \pm 0.19 \mathrm{ab}$ & $0.87 \pm 0.13 \mathrm{a}$ & $2460.18 \pm 1364.80 \mathrm{ab}$ \\
\hline AUTUMN (Mar. Apr. May) & $19.59 \pm 1.42 b$ & $2.45 \pm 0.74 b$ & $2.58 \pm 0.25 \mathrm{a}$ & $0.93 \pm 0.18 \mathrm{a}$ & $2058.07 \pm 1145.90 b$ \\
\hline WINTER (Jun. Jul. Aug.) & $22.80 \pm 3.09 \mathrm{a}$ & $3.54 \pm 0.75 \mathrm{ab}$ & $2.56 \pm 0.27 \mathrm{ab}$ & $1.06 \pm 0.21 \mathrm{a}$ & $2789.87 \pm 1396.00 \mathrm{a}$ \\
\hline
\end{tabular}

Means and standard deviations of crude protein - CP, lipids - LP, ashes, vitamin C and total flavonoids (expressed in $\mu \mathrm{g} 100 \mathrm{~g}^{-1}$ rutin). Different lowercase letters, in the same column indicate differences between the means (ANOVA, Tukey's test, $\mathrm{P} \leq 0.05$ ).

TABLE III

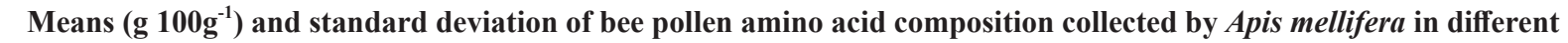
seasons.

\begin{tabular}{|c|c|c|c|c|}
\hline \multicolumn{5}{|c|}{ SEASONS } \\
\hline $\begin{array}{l}\text { Amino acid } \\
(\mathrm{g} / 100 \mathrm{~g})\end{array}$ & $\begin{array}{c}\text { SPRING } \\
\text { (Sep. Oct. Nov.) }\end{array}$ & $\begin{array}{c}\text { SUMMER } \\
\text { (Dec. Jan. Feb.) }\end{array}$ & $\begin{array}{c}\text { AUTUMN } \\
\text { (Mar. Apr. May) }\end{array}$ & $\begin{array}{c}\text { WINTER } \\
\text { (Jun. Jul. Aug.) }\end{array}$ \\
\hline Alanine & $0.949 \pm 0.29$ & $1.154 \pm 0.05$ & $0.978 \pm 0.03$ & $0.922 \pm 0.14$ \\
\hline Arginine & $0.716 \pm 0.06$ & $0.875 \pm 0.17$ & $0.715 \pm 0.03$ & $0.884 \pm 0.24$ \\
\hline Aspartic Acid & $1.554 \pm 0.22$ & $1.607 \pm 0.10$ & $1.401 \pm 0.00$ & $1.660 \pm 0.21$ \\
\hline Glutamic Acid & $1.766 \pm 0.29$ & $1.815 \pm 0.15$ & $1.563 \pm 0.08$ & $1.885 \pm 0.30$ \\
\hline Cysteine & $0.192 \pm 0.04$ & $0.284 \pm 0.06$ & $0.276 \pm 0.03$ & $0.219 \pm 0.07$ \\
\hline Phenylalanine & $0.650 \pm 0.11$ & $0.715 \pm 0.06$ & $0.600 \pm 0.01$ & $0.696 \pm 0.08$ \\
\hline Glycine & $0.772 \pm 0.15$ & $0.833 \pm 0.05$ & $0.712 \pm 0.00$ & $0.799 \pm 0.12$ \\
\hline Histidine & $0.421 \pm 0.13$ & $0.458 \pm 0.04$ & $0.402 \pm 0.03$ & $0.387 \pm 0.05$ \\
\hline Isoleucine & $0.627 \pm 0.18$ & $0.717 \pm 0.07$ & $0.567 \pm 0.02$ & $0.671 \pm 0.04$ \\
\hline Leucine & $1.115 \pm 0.13$ & $1.259 \pm 0.95$ & $1.067 \pm 0.02$ & $1.217 \pm 0.13$ \\
\hline Lysine & $1.112 \pm 0.36$ & $1.169 \pm 0.01$ & $0.978 \pm 0.03$ & $1.065 \pm 0.21$ \\
\hline Methionine & $0.432 \pm 0.08$ & $0.518 \pm 0.03$ & $0.512 \pm 0.01$ & $0.555 \pm 0.06$ \\
\hline Proline & $1.654 \pm 0.54$ & $2.124 \pm 0.29$ & $2.152 \pm 0.14$ & $2.364 \pm 0.62$ \\
\hline Serine & $0.857 \pm 0.15$ & $0.989 \pm 0.04$ & $0.897 \pm 0.03$ & $0.876 \pm 0.13$ \\
\hline Tyrosine & $0.386 \pm 0.04$ & $0.463 \pm 0.15$ & $0.400 \pm 0.00$ & $0.428 \pm 0.01$ \\
\hline Threonine & $0.616 \pm 0.10$ & $0.673 \pm 0.03$ & $0.600 \pm 0.01$ & $0.662 \pm 0.10$ \\
\hline Tryptophan & $0.198 \pm 0.02$ & $0.213 \pm 0.00$ & $0.178 \pm 0.00$ & $0.212 \pm 0.01$ \\
\hline Valine & $0.670 \pm 0.13$ & $0.842 \pm 0.12$ & $0.676 \pm 0.02$ & $0.752 \pm 0.09$ \\
\hline
\end{tabular}

Regarding the Vitamin C levels, we found no differences $(\mathrm{P}>0.05)$ between them in the seasons where the pollen was collected (Table II).

The winter period had the highest average for flavonoid content, differing only from autumn and spring that showed lower levels (Table II).

We found no differences $(\mathrm{P}>0.05)$ for the evaluated amino acids, when compared between different seasons (Table III).

\section{DISCUSSION}

Our results show that not only pollen production undergoes changes throughout the different seasons, as well as its nutritional composition. It is also known that Apis mellifera L. bees are considered polyletics insects, because they collect pollen from different botanical varieties and can select apicultural interest species in accordance 
with the food quality or offered resource (Thorp 1979), suggesting that foraging behavior can range from the swarms of the same apiary.

\section{BEE POLLEN PRODUCTION AND BOTANICAL ORIGIN}

The pollen harvesting was more favorable in the winter, being characterized as a dry season, with low precipitations, making it easier to bees collects the food. In rainy periods the foraging activity decreases, besides the swarm population is reduced when there is excess of relative air humidity (Carpes et al. 2009). Also for the winter period, we observed predominance of Myrtaceae family, included among the ten families with highest species richness in Brazil, with 23 genera and 976 species, including trees, shrubs and subshrubs; furthermore, this predominance can be associated with this variety provision in the bees foraging area and also by this family large pollen production, which makes it a resource more easily acquired (Sobral et al. 2012).

In the autumn season, we observed few botanical varieties around the apiary, which may explain the pollen production decrease for this period. Consequently, the food low availability also influences the harvesting activity oh foraging bees, since it promotes a decrease population colony size, mainly in the brood amount, which exerts a stimulatory effect on pollen collection (Barker 1971).

In all seasons we find pollen grains of Myrtaceae, Asteraceae and Poaceae families, serving as a food source for the bees throughout the year, which can be related to these plants attractiveness, influenced by the amount of pollen produced, flowers concentration and abundance, number of competitors insects, distance between flower and nest and species innate preference (Willmer 2011).

Several pollens found classified as IIP or OIP by being present at less than $15 \%$ of the observed grains. This could be explained by the fact that pollen types with low collection concentration would serve as a secondary resource with little appeal. This pollen types can, eventually serve as a complement to the colony food needs and becomes important for maintaining their balance, for short periods, when the resources supply is subject to seasonal variations (Modro et al. 2011).

\section{Bee pollen chemical composition}

In our study we observed that the highest protein content in pollen was found in winter, season in which the swarms are most difficult to maintain the brood area due to low temperatures characteristics of this period, making it necessary the search and selection of more advantageous floral resources for swarm maintenance, since the brood care may be suspended altogether when pollen reservations is exhausted (Brodschneider and Crailsheim 2010).

This higher protein content is probably related to the presence of a larger variety of plant species collected by bees during this period, exalting the significance of knowledge on bee pollen origin and nutritional value produced in a certain region, since the development of bees hypopharyngeal glands and ovaries are correlated with the protein portion present in pollen (Pernal and Currie 2000).

However, some studies show that the amino acid composition can define pollen nutritional value more accurately than the protein content, once this nutritional value is reduced when there are insufficient amounts of essential amino acids (Cook et al. 2003).

According to Campos et al. (2008), 17 different amino acids may be present in pollen loads whereas proline, glutamic acid, aspartic acid, lysine and leucine are dominant, constituting approximately $55 \%$ of the total amino acids. Despite expressing themselves in values below $55 \%$, there was also a predominance of these amino acids in this work, 
with variations of $49 \%$ for spring, $47.7 \%$ for the summer, $48.8 \%$ for fall and $50.4 \%$ for the winter.

In bee pollen collected during this study, we found a total of 18 amino acids in its composition, and this product has all the essential amino acids for the bees development. We did not observe significant differences $(\mathrm{P}>0.05)$ in amino acid contents amongst seasons, suggesting that even if the total protein contents vary, amino acid levels remain constant. This fact is extremely important, because even with harvest reduction in the Field, bees ensure adequate nutrition for the proper brood development, avoiding deficiency symptoms and protein synthesis problems (Brodschneider and Crailsheim 2010).

The pollen lipid fraction has more attractive substances for bees; thus, plants with pollen with high lipid concentrations are more likely to be visited (Dobson 1988). This may also explain the greater presence of pollen from Asteraceae sp.1, Poaceae sp.1, Poaceae sp.2, Myrtaceae sp.1 and Mimosaceae families, being that the pollen grain numbers counted in the last three families were more numerous for the spring season, which showed a higher lipid content.

For the ash content, which is the pollen inorganic fraction, we observed that our values ranged from $2.22 \pm 0.39$ and $2.58 \pm 0.25 \%$, which are lower than the results obtained by AlmeidaMuradian (2005) in southern Brazil samples.

Few studies have reported the presence of vitamin $\mathrm{C}$ in the pollen, which is an important nutrient because it assists in bees' development during the larval stage. In general, the colony vitamin requirements will be met while there is pollen storage in beehive combs (Standifer 2007). We did not observe differences in the vitamin $\mathrm{C}$ content among seasons in this study, showing that the concentrations found for this nutrient can satisfy the colony maintenance.

We observed that the winter showed greater concentrations of total flavonoids (2789.87 \pm
$1396.00 \mu \mathrm{g} 100 \mathrm{~g}^{-1}$ ) and may be related to the higher plant variation found in the apiary this time of year, since studies show that the flavonoids contribution in pollen composition differs considerably according to its botanical origin. It is also known that the flavonoids intake interferes in several physiological processes, and may help in the vitamins absorption and action, in addition to presenting modulating activity of the immune system (Leja et. al. 2007), becoming interesting for bees to collect a more nutritional product during the most difficult periods to maintain the swarm.

We can conclude that the pollen harvest season influences its production and also its chemical composition due to differences in vegetation present around the apiary. We observed that despite its adverse weather conditions, the winter season was more favorable to the food collection with better nutritional quality. Our results highlight the importance of knowing the botanical origin and pollen composition in areas where the hives are installed, so that it can provide an artificial food supply in shortage periods.

\section{ACKNOWLEDGMENTS}

We are grateful to Fundação de Amparo à Pesquisa do Estado de São Paulo (FAPESP) (2010/06074-8) for the scholarship and financial support provided.

\section{REFERENCES}

ALMEIDA-MURADIAN LB, PAMPLONA LC, COIMBRA S AND BARTH OM. 2005. Chemical composition and botanical evaluation of dried bee pollen pellets. J Food Comp Anal 18: 105-111.

ARAÚJO WAG, ASSIS FI AND SOBREIRA GF. 2007. Fundamentos e métodos para análise de aminoácidos. Rev Eletron Nutrit 4: 395-404.

ARRUDA VAS, PEREIRA AAS, FREITAS AS, BARTH OM AND ALMEIDA-MURADIAN LB. 2013. Dried bee pollen: B complex vitamins, physicochemical and botanical composition. J Food Comp Anal 29: 100-105.

AWAD MA, DE JAGER A AND VAN WESTING LM. 2000. Flavonoid and chlorogenic acid levels in apple fruit: characterisation of variation. Scien Hortic 83(3): 249-263. 
BARKER RJ. 1971. Influence of food inside the hive on pollen collection by a honeybee colony. J Apic Res 10: 23-26.

BARTH OM. 1998. Pollen analysis of Brazilian Propolis. Grana 37: 97-101.

BOGDANOV S. 2011. Pollen: Nutrition, Functional Properties, Health: A Review. Bee Product Science. http://www.bee-hexagon.net/files/file/fileE/Health/ PollenBook2Review.pdf (Accessed on Aug. 21, 2014).

BRODSCHNEIDER R AND CRAILSHEIM K. 2010. Nutrition and health in honey bees. Apidologie 41: 278294.

CAMPOS MG, BOGDANOV S, ALMEIDA-MURADIAN LBD, SZCZESNA T, MANCEBO Y, FRIGERIO C AND FERREIRA F. 2008. Pollen composition and standardisation of analytical methods. J Apic Res 47(2): 154.

CARPES ST, CABRAL IS, LUZ CFP, CAPELETTI JP, ALENCAR SM AND MASSON ML. 2009. Palynological and physicochemical characterization of Apis mellifera L. bee pollen in the Southern region of Brazil. J Food Agric Environ 7: 667-673.

COOK SM, AWMACK CS, MURRAY DA AND WILLIAMS IH. 2003. Are honey bees' foraging preferences affected by pollen amino acid composition? Ecol Entomol 28(5): 622-627.

CRONQUIST A. 1988. The evolution and classification of flowering plants. New York: The New Work Botanical Garden.

DOBSON HEM. 1988. Survey of pollen and pollenkitt lipidschemical cues to flower visitors. Am J Bot 75: 170-182.

ERDTMAN G. 1960. The acetolysis method - a revised description. Svensk Bot Tidsk 54: 561-564.

ESTEVINHO LM, RODRIGUES S, PEREIRA AP AND FEÁS X. 2012. Portuguese bee pollen: palynological study, nutritional and microbiological evaluation. Int $\mathbf{J}$ Food Scienc Technol 47(2): 429-435.

HUMAN H AND NICOLSON SW. 2006. Nutritional content of fresh, bee-collected and stored pollen of Aloe greatheadii var. davyana (Asphodelaceae). Phytochemistry 67(14): 1486-1492.

IAL - INSTITUO ADOLFO LUTZ. 2005. Normas analíticas do Instituto Adolfo Lutz. São Paulo: O Instituto, 1018 p.

KÖPPEN W AND GEIGER R. 1928. Klimate der Erde. Gotha: Verlag Justus Perthes.

LEJA M, MARECZEK A, WYŻGOLIK G, KLEPACZBANIAK J AND CZEKOŃSKA K. 2007. Antioxidative properties of bee pollen in selected plant species. Food Chem 100(1): 237-240.
MODRO AFH, MARCHINI LC AND MORETI ACDCC. 2011. Origem botânica de cargas de pólen de colmeias de abelhas africanizadas em Piracicaba, SP. Cienc Rural 41(11): 1944-1951.

MORETI ACCC, FONSECA TC, RODRIGUEZ APM, MONTEIRO-HARA ACBA AND BARTH OM. 2007. Fabaceae forrageiras de interesse apícola. Aspectos botânicos e polínicos. Bol Cient 13: 98.

NICOLSON SW AND HUMAN H. 2013. Chemical composition of the 'low quality'pollen of sunflower (Helianthus annuus, Asteraceae). Apidologie 44(2): 144152.

PCHELOVODSTVO AN. 1999. Influência del nível de proteína bruta em la produccion de la colônia de abejas. Apiacta 12(14): 23-54.

PERNAL SF AND CURRIE RW. 2000. Pollen quality of fresh and 1-year-old single pollen diets for worker honey bees (Apis mellifera L.). Apidologie 31: 387-409.

ROULSTON TH, CANE JH AND BUCHMANN SL. 2000. What governs protein content of pollen: pollinator preferences, pollen pistil interactions, or phylogeny? Ecol Monagr 70: 617-643.

SANTOS MDD AND BLATT CTT. 1998. Teor de flavonóides e fenóis totais em folhas de Pyrostegia venusta Miers. de mata e de cerrado. Braz J Bot 21(2): 135-140.

SOBRAL M, PROENÇA C, SOUZA M, MAZINE F AND LUCAS E. 2012. Myrtaceae in Lista de Espécies da Flora do Brasil. Jardim Botânico do Rio de Janeiro. <http:// floradobrasil.jbrj.gov.br/2012/FB000171>. (Acesso em 4 Set., 2014)

STANDIFER LN. 2007. Honey bee nutrition and supplemental feeding. Beekeeping in the United States. http://www. beesource.com/resources/usda/honey-bee-nutrition-andsupplemental-feeding/. (Accessed on Aug. 30, 2014).

SZCZESNA T, RYBAK-CHIELEWSKA H AND CHMIELEWSKI W. 2002. Sugar composition of pollen loads harvested at different periods of the beekeeping season. J Apic Scienc 46(2): 107-115.

THORP RW. 1979. Structural, behavioral, and physiological adaptations of bees (Apoidea) for collecting pollen. Ann Mo Bot Gard 66(4): 788-812.

WILLMER P. 2011. Pollination and floral ecology. Princeton University Press, $771 \mathrm{p}$.

YANG K, WU D, YE X, LIU D, CHEN J AND SUN P. 2013. Characterization of chemical composition of bee pollen in china. J Agric Food Chem 61(3): 708-718.

ZAR JH. 2010. Bioestatistical analysis. Pretince Hall, New Jersey, $944 \mathrm{p}$. 